\title{
Diabetes Mellitus Among Hospitalized Patients in Mukalla City, Yemen: Prevalence, symptoms and complications
}

Abdulla Salem Bin-Ghouth ( $\sim$ abinghouth2007@yahoo.com )

Hadhramout University https://orcid.org/0000-0002-0884-5361

Riyadh Awadh AL-Hamed

Hadhramout University

Mohammed Abdualhakem Bin-Sema

Hadhramout University

Ahmed Hussein Bin-Askar

Hadhramout University

Essa Saleh Kanad

Hadhramout University

Mahdi Zaid Muhaimudan

Hadhramout University

Akram khamis Ba-Gubair

Hadhramout University

Akram Ahmed Askander

Hadhramout University

Marei Mohsen Balhman

Hadhramout University

Naif Hassan Blhmad

Hadhramout University

Saleh Naser Al-Rmaay

Hadhramout University

Mohsen Awadh Al-Solaimani

Hadhramout University

Abdualsalam Khaled Bin-Menif

Hadhramout University

Mohammed Adel Hassan

Hadhramout University

Mohammed Ahmed Mater

Hadhramout University

Osama Saleh Qhadair 
Hadhramout University

Wahballah Mohammed Mashikhy

Hadhramout University

Nasser Ali Al-Aqil

Hadhramout University

\section{Research Article}

Keywords: DM, Hospitalized patients, Mukalla

Posted Date: October 8th, 2021

DOl: https://doi.org/10.21203/rs.3.rs-958560/v1

License: (c) (7) This work is licensed under a Creative Commons Attribution 4.0 International License. Read Full License 


\section{Abstract}

The purpose: The aim of this study is to determine the burden of DM among patients admitted to tertiary hospitals in Mukalla city at eastern Yemen.

Patients and methods: It is a cross sectional study among patients admitted to in three main hospitals in Mukalla city.

Results: the prevalence of DM among admitted patients to the three hospitals in Mukalla city is $16.6 \%$. Age specific prevalence rate is higher among adults over 40 years $(40.3 \%)$ than the younger patients (2.2\%). In a logistic regression only, age is a determinate factor to DM. The main symptoms and signs of the hospitalized DM patients are: polyurea (72.6\%), polydipsia (70.5\%), blurring of vision ( $57.9 \%)$, marked loss of weight (54.7\%) Paresthesia (51.2\%) and polyphagia (34.7\%). The main complications among hospitalized DM patients are difficulty of vision (60.8\%), Foot ulcer (53.6\%) and loss of libido (49.2\%).

Conclusion: The prevalence of DM among hospitalized patients is high.

\section{Introduction}

At present, chronic diseases are reflected to be a growing public health issue worldwide. ${ }^{182}$ Diabetes Mellitus (DM) is a group of metabolic disorders characterized by raised blood sugar levels or blood glucose levels, if not treated,

might leads to serious impairment of the vision, blood vessels, heart, kidneys, and nerves over time. ${ }^{3 \& 4}$ Diabetes is a serious ailment that affects the quality of life, life expectancy, and health of an individual. Thus, placing a substantial economic burden on the healthcare system.

Diabetes mellitus is a global public health problem that affecting humans and threaten their life's. The global diabetes prevalence in adults (aged above 18) has increased from "4.7\% in 1980 to $8.5 \%$ in 2014". The predominance has been elevated swiftly in low and middle-income countries. ${ }^{5}$ In the middle-east there are three countries' has been classified among the top ten countries with higher prevalence of diabetes are Saudi Arabia (23.9\%), Kuwait (23.1\%) and Qatar (22.9\%). ${ }^{6}$

Although there are common persecution among doctors in Yemen that DM is a common problem in Yemen; but studies about DM were scarce in the country. Recently published study in 2019 estimated the prevalence of DM among men in Yemen is $9.8 \%{ }^{7}$ While one old study (published in 2004) reported that the overall prevalence of type II DM in Yemen was 4.6\% (7.4\% in males and $2 \%$ in females), ${ }^{17}$ this study focusing on Type II Diabetes Mellitus and its relation with the impaired glucose tolerance and found that impaired Glucose Tolerance (IGT) and Impaired Fasting Glucose (IFG) were found in $2 \%$ and $2.2 \%$ of the study population. ${ }^{[17]}$. The prevalence of type II DM and its potential increase reflected by the 
high prevalence of obesity in normal Glucose Tolerance subjects in the Yemeni population constitutes a major public health problem. ${ }^{8}$

Access to health services, cost of DM diagnosis and treatment as well as weak research capacity are challenges to understand the size of the DM problem in the country and specifically at sub-national and remote governorates. Mukalla city is the capital of Hadhramout governorate at eastern Yemen, the city population is about 291,873 inhabitants. ${ }^{9}$ In Mukalla city; health services are provided through three main tertiary hospitals and a network of health centers and district hospitals as well as the private sector. The three tertiary and referral hospitals are public hospitals; they are Ibn Sina hospital, University Hospital and the Maternity and childhood hospital. Up to our knowledge; no study addresses the DM as a common problem from the available data in the hospitals. So, the aim of the is study is determining the burden of DM among patients admitted to tertiary hospitals in Mukalla city in Yemen and to describe the clinical patterns of those Diabetic patients.

\section{Patients And Methods}

It is a cross sectional study carried out in Al-Mukalla city, the settings are the three tertiary public hospitals (Ibn Sina hospital, University Hospital and the Maternity and childhood hospital Ibn-Sina hospital, University Hospital and the Maternity and childhood hospital). The study targeted all patients admitted to the three mentioned hospitals during the period the period 7th of November 2019 to 7th of February 2020 and agree to participate; a detailed data then collected from DM Patients. A group of 5th year medical students of Hadharmout University were trained to collect data from the admitted patients though a pre-tested questionnaire. The questionnaire composed of four parts: part I and part II include personal data and patient diagnosis. part III and IV only for DM patients. (Part III: Type of DM and treatment. Part IV: Symptoms and complications of DM).

The data was checked for completeness, coded then entered into computer by using statistical package for social science (SPSS version 23). Then analyzed by using descriptive statistical tools (frequencies, percentage, mean and standard deviation), chi-square is be used to test associations between independent and dependent variables. The level of statistical significance is $p<0.05$.

\section{Operational definition used:}

- Type $1 \mathrm{DM}$ results from the body's failure to produce insulin, and presently requires the person to inject insulin. This usually develops in children or young adults but can occur at any age. (Also referred to as insulin-dependent diabetes mellitus (IDDM) or "juvenile" diabetes). ${ }^{10}$

- Type 2 DM (Formerly called adult onset) results from insulin resistance, a condition in which cells fail to use insulin properly, sometimes combined with an absolute insulin deficiency. (Formerly referred to as noninsulin-dependent diabetes mellitus (NIDDM) or "adult-onset" diabetes). ${ }^{10}$

\section{Ethical consideration}


Approval of the study proposal was obtained from Hadhramout University College of Medicine, Department of Community Medicine in 2019. Objectives of the study were explained for participants and those who agree to participate were involved in study and those who refused to participate were excluding from study.

\section{Results}

The mean age of all patients admitted to the three hospitals in Mukalla city is 34.8 years $( \pm 23.7)$ and the median age of 31 years with a wide range of age from one year to 95 years.

During the study period; a total of 574 patients admitted to the studied three hospitals in Mukalla city during three months, out of them 95 patients are diabetic giving the prevalence of DM among admitted patients to $16.6 \%$. Based on the type of health facility; Ibn-Sina hospital is used to provide care to adults only (Medical and surgical health services) the prevalence of DM among patients admitted to Ibn-Sina hospital is significantly higher among all the other hospitals $(90 / 403,22.3 \%)(P$-value $=0.000)$. while the prevalence of DM among patients admitted to the University hospital (provide care to children and mothers) is $5.8 \%(5 / 86)$ and no diabetic patients admitted to the Maternity and childhood hospital $(n=85)$. The prevalence of DM among patients admitted to medical department is high $(28.5 \%)$ followed by the prevalence of DM admitted to surgical department (15.4\%) while it is very low in Gyn\&Obs department (5.8\%) and never among children admitted to pediatric departments. (Table1)

Significant variations are reported regarding age group where adults over 40 Years have higher prevalence $(40.3 \%)$ than younger $2.2 \%(P$-value $=0.000)$. While there is no significant variations regarding gender, the prevalence of DM among males admitted to hospitals is $18.7 \%$ while among admitted females is $14.2 \%(P$-value $=0.088)$. Table. 1

In logistic regression analysis only the age group is associated with $\mathrm{DM}\left(\mathrm{OR}=4, \mathrm{Cl}_{95 \%} 3.18-4.82, P\right.$-value $=0.000)$. Table. 2

Table1. Prevalence of DM among patients admitted to the three tertiary hospitals in Mukalla city 


\begin{tabular}{|c|c|c|c|c|c|c|}
\hline \multicolumn{2}{|c|}{ Setting / age and gender } & \multirow{2}{*}{$\begin{array}{l}\text { Total } \\
\text { admitted } \\
\text { patients } \\
403\end{array}$} & \multirow{2}{*}{$\begin{array}{l}\text { DM } \\
\text { patients } \\
90\end{array}$} & \multirow{2}{*}{$\begin{array}{l}\text { Prevalence \% of DM } \\
\text { among admitted } \\
\text { patients } \\
22.2 \%\end{array}$} & \multirow{2}{*}{$\begin{array}{l}x^{2} \\
33.7\end{array}$} & \multirow{2}{*}{$\begin{array}{l}\begin{array}{l}P- \\
\text { value }\end{array} \\
0.000\end{array}$} \\
\hline Hospital & Ibn-Sina & & & & & \\
\hline & $\begin{array}{l}\text { University } \\
\text { Hospital }\end{array}$ & 86 & 5 & $5.8 \%$ & & \\
\hline & $\begin{array}{l}\text { Maternity } \\
\text { and } \\
\text { childhood }\end{array}$ & 85 & 0 & $0 \%$ & & \\
\hline & Total & 574 & 95 & $16.6 \%$ & & \\
\hline \multirow[t]{5}{*}{ Department } & Medical & 215 & 61 & $28.4 \%$ & \multirow[t]{5}{*}{46.5} & \multirow[t]{5}{*}{0.000} \\
\hline & Surgical & 188 & 29 & $15.4 \%$ & & \\
\hline & Gy\&Obes & 69 & 5 & $7.3 \%$ & & \\
\hline & Pediatric & 102 & 0 & $0 \%$ & & \\
\hline & Total & 574 & 95 & $16.6 \%$ & & \\
\hline \multirow[t]{3}{*}{ Gender } & Male & 299 & 56 & $18.7 \%$ & \multirow[t]{3}{*}{2.1} & \multirow[t]{3}{*}{0.088} \\
\hline & Female & 275 & 39 & $14.2 \%$ & & \\
\hline & Total & 574 & 95 & $16.6 \%$ & & \\
\hline \multirow[t]{3}{*}{ Age Group } & $>40$ years & 216 & 87 & $40.3 \%$ & \multirow[t]{3}{*}{141} & \multirow[t]{3}{*}{0.000} \\
\hline & $\leq 40$ years & 358 & 8 & $2.2 \%$ & & \\
\hline & Total & 574 & 95 & $16.6 \%$ & & \\
\hline
\end{tabular}

Table 2. Logistic regression analysis of the role of age group, gender and type of hospital and department to the prevalence of SM among admitted patients in the three tertiary hospitals in Mukalla city, Yemen

\begin{tabular}{|llll|}
\hline Variable & $\operatorname{Exp}(\mathrm{B})$ & $\mathrm{Cl}_{95 \%}$ & $P$-value \\
\hline Hospital name & 1.966 & $0.665-5.812$ & .222 \\
\hline Department & 1.008 & $0.584-1.739$ & .978 \\
\hline Age group & 4 & $3.18-4.82$ & .000 \\
\hline Gender & 1.222 & $0.713-2.096$ & .466 \\
\hline
\end{tabular}




\section{Description of the hospitalized DM patients:}

Most of the hospitalized patients are of type II DM (64.2\%) while $35.8 \%$ of them of type I DM. There is no significant association between type of DM and age $\left(\mathrm{OR}=0.526, \mathrm{Cl}_{95 \%} 1.23-2.25, P\right.$-value $\left.=0.451\right)$. or gender $\left(\mathrm{OR}=0.833, \mathrm{Cl}_{95 \%} 0.353-1.96, P\right.$-value $\left.=0.423\right)$ Table 3 .

\section{Table 3. Types of DM according to age group and gender}

\begin{tabular}{|c|c|c|c|c|c|c|c|}
\hline \multicolumn{2}{|c|}{ Age and gender } & $\begin{array}{l}\text { Type } 1 \text { DM } \\
\text { No (\%) }\end{array}$ & $\begin{array}{l}\text { Type } 2 \text { DM } \\
\text { No }(\%)\end{array}$ & Total & OR & $\mathrm{Cl}_{95 \%}$ & $P$-value \\
\hline \multirow[t]{3}{*}{ Age group } & $>40$ years & 30 (34.5\%) & 57 (65.5\%) & 87 & 0.526 & $1.23-2.25$ & 0.451 \\
\hline & $\leq 40$ years & $4(50 \%)$ & $4(50 \%$ & 8 & & & \\
\hline & Total & $34(35.8 \%)$ & $61(64.2 \%)$ & 95 & & & \\
\hline \multirow[t]{3}{*}{ Gender } & Male & $21(37.5 \%)$ & 35 (62.5\%) & 56 & 0.833 & $0.353-1.96$ & 0.423 \\
\hline & Female & $13(33.3 \%)$ & $26(66.7 \%)$ & 39 & & & \\
\hline & Total & $34(35.8 \%)$ & $61(64.2 \%)$ & 95 & & & \\
\hline
\end{tabular}

The main symptoms and signs of the hospitalized DM patients in Mukalla city are: polyurea $(72.6 \%)$, polydipsia (70.5\%), blurring of vision (57.9\%), marked loss of weight (54.7\%) Paresthesia $(51.2 \%)$ and polyphagia (34.7\%). There are no significant difference in symptoms and sign between type I and type 2 DM. Table 4

Table 4. Symptoms and Signs of Diabetic patients at the time of hospital admission 


\begin{tabular}{|lllllll|}
\hline Symptoms/Signs & $\begin{array}{l}\text { Type 1 DM } \\
(\mathrm{n}=25)\end{array}$ & $\begin{array}{l}\text { Type 2 DM } \\
(\mathrm{n}=44)\end{array}$ & $\begin{array}{l}\text { Total } \\
(\mathrm{N}-95)\end{array}$ & OR & $\mathrm{Cl}_{95 \%}$ & P-value \\
& No $(\%)$ & No $(\%)$ & No $(\%)$ & & \\
\hline Polyurea & 27 & $\begin{array}{l}42 \\
(79.4 \%)\end{array}$ & $69(72.6 \%)$ & 0.559 & $\begin{array}{l}0.207- \\
1.51\end{array}$ & 0.338 \\
\hline Polydipsia & $23(67.7 \%)$ & $44(72 \%)$ & $67(70.5 \%)$ & 1.31 & $\begin{array}{l}0.525- \\
3.29\end{array}$ & 0.637 \\
\hline Blurring of vision & $18(53 \%)$ & $37(60.3 \%)$ & $55(57.9 \%)$ & 1.37 & $\begin{array}{l}0.587- \\
3.19\end{array}$ & 0.519 \\
\hline $\begin{array}{l}\text { Marked loss of } \\
\text { weight }\end{array}$ & $18(53 \%)$ & $34(55.7 \%)$ & $52(54.7 \%)$ & 1.02 & $0.434-2.39$ & 1 \\
\hline Paresthesia & $18(53 \%)$ & $31(50.8 \%)$ & $49(51.2 \%)$ & 0.921 & $\begin{array}{l}0.393- \\
2.15\end{array}$ & 1 \\
\hline Polyphagia & $14(41 \%)$ & $19(31 \%)$ & 33 & 0.646 & $\begin{array}{l}0.270- \\
1.54\end{array}$ & 0.373 \\
\hline
\end{tabular}

\section{Complications among DM patients at the time of hospital admission}

The main complications among hospitalized DM patients are difficulty of vision (60.8\%), Foot ulcer (53.6\%) and loss of libido (49.2\%) but there are no significant difference between type 1 and Type 2 DM. The only significant difference due to exposure to fungal infection (35.7\%) between type $1 \mathrm{DM}$ patients $(34.6 \%)$ and type $2 \mathrm{DM}$ patients $\left(\mathrm{OR}=1.82, \mathrm{Cl}_{95 \%} 1.06-3.12, P\right.$-value $\left.=0.032\right)$. The least complications are renal failure (28.8\%), coma (14.4\%) and ketoacidosis (13\%), Table. 5

\section{Table 5. Compilations of DM among the hospitalized patients}




\begin{tabular}{|c|c|c|c|c|c|c|}
\hline Complications & $\begin{array}{l}\text { Type } 1 \\
\text { DM } \\
(\mathrm{n}=25)\end{array}$ & $\begin{array}{l}\text { Type } 2 \\
\text { DM } \\
(n=44)\end{array}$ & $\begin{array}{l}\text { Total DM patients with } \\
\text { complications } \\
(n=69)\end{array}$ & OR & $\mathrm{Cl}_{95 \%}$ & $\begin{array}{l}P \text { - } \\
\text { value }\end{array}$ \\
\hline $\begin{array}{l}\text { Vision } \\
\text { difficulty }\end{array}$ & $\begin{array}{l}15 \\
(55.7 \%)\end{array}$ & $\begin{array}{l}27 \\
(61.4 \%)\end{array}$ & $42(60.8 \%)$ & 1.05 & $\begin{array}{l}0.388- \\
2.89\end{array}$ & 1 \\
\hline Foot ulcer & $\begin{array}{l}16 \\
(64 \%)\end{array}$ & $\begin{array}{l}21 \\
(47.2 \%)\end{array}$ & $37(53.6 \%)$ & 0.514 & $\begin{array}{l}0.187- \\
1.40\end{array}$ & 0.219 \\
\hline Loss of libido & $\begin{array}{l}10 \\
(40 \%)\end{array}$ & $\begin{array}{l}24 \\
(54.5 \%)\end{array}$ & $34(49.2 \%)$ & 1.80 & $\begin{array}{l}0.665- \\
0.487\end{array}$ & 0.318 \\
\hline $\begin{array}{l}\text { Fungal } \\
\text { infection }\end{array}$ & $\begin{array}{l}19 \\
(55.8 \%)\end{array}$ & $\begin{array}{l}15 \\
(24.6 \%)\end{array}$ & 34 (35.7\%) & 1.82 & $\begin{array}{l}1.06- \\
3.12\end{array}$ & $0.032^{*}$ \\
\hline Hypoglycemia & $\begin{array}{l}11 \\
(44 \%)\end{array}$ & $\begin{array}{l}20 \\
(45 \%)\end{array}$ & $31(45 \%)$ & 1.06 & $\begin{array}{l}0.359- \\
2.85\end{array}$ & 1 \\
\hline Renal failure & $7(28 \%)$ & $\begin{array}{l}13 \\
(29.5 \%)\end{array}$ & $20(28.8 \%)$ & 1.07 & $\begin{array}{l}0.364- \\
0.319\end{array}$ & 1 \\
\hline Coma & $4(16 \%)$ & $\begin{array}{l}6 \\
(13.6 \%)\end{array}$ & $10(14.4 \%)$ & 0.829 & $\begin{array}{l}0.210- \\
3.27\end{array}$ & 1 \\
\hline Keto-acidosis & $4(16 \%)$ & $\begin{array}{l}5 \\
(11.4 \%)\end{array}$ & $9(13 \%)$ & 0.673 & $\begin{array}{l}0.163- \\
2.77\end{array}$ & 0.714 \\
\hline
\end{tabular}

\section{*significant}

\section{Patient Adherence to treatment}

About 26 out of 34 Type 1 DM patients are adherent to regular insulin therapy (76.5\%); the same finding is found among Type 2 DM patients who under regular hypoglycemic drugs (43/61, 70.5\%). Figure 1

\section{Discussion}

This study revealed that the prevalence of DM among hospitalized patients in Mukalla city in Yemen is $16.6 \%$ which is less than studies in neighboring countries as in Saudi Arabia $23.9 \%$, Kuwait $23.1 \%$, and Qatar 22.9\%. ${ }^{11}$ In UK; Data from the National In-patient Diabetes Audit suggested that around 1 in 5 inpatient beds are occupied by a person with diabetes. ${ }^{12}$

A very high prevalence of DM in hospitalized patients in one tertiary hospital is Nigeria was reported by Maori $\mathrm{L}$ et al in 2014 ( 40.5\%). ${ }^{10}$ This high prevalence may be explained by that hospitalized patients may have co-morbidities or complications, for example data from the Massachusetts General Hospital indicated that Among 450 admitted COVID-19 patients, 178 (39.6\%) had diabetes-mostly type 2 diabetes. ${ }^{13}$ Low prevalence of DM in hospitalized patients was reported in Ethiopia where In one referral hospital in Addis Ababa out of 8048 admissions, 523 (6.5\%) had DM between 2010 and 2013. ${ }^{14}$ 
The American Diabetes Association (ADA) lists seven symptoms of diabetes; as follows: frequent urination, excessive thirst, extreme hunger, unusual weight loss, increased fatigue, irritability, and blurry vision it however, is not known how specific these symptoms are common in Yemeni diabetic patients. ${ }^{15}$ In this study in Mukalla; The most frequently symptoms reported by diabetic patients are: polyurea, polydipsia, blurring of vision, marked loss of weight, paresthesia and polyphagia, but there is no significant difference between type 1 and type $2 \mathrm{DM}$. The proportion of symptoms in this study is looking high, because about $25 \%$ of diabetic patients are subject to irregular treatment. Poor adherence of diabetic patients leads to complications. These complications occur in the majority of individuals with both type 1 and type 2 diabetes. Among the most prevalent micro-vascular complications are kidney disease, blindness, and amputations, with current therapies only slowing disease progression. Impaired kidney function, exhibited as a reduced glomerular filtration rate. ${ }^{16}$ In this study; the most common complications among diabetic patients of both types are: difficulty vision (retinopathy). Foot ulcer and loss of libido but the only significant difference due to exposure to fungal infection between type $1 \mathrm{DM}$ patients and type 2 DM patients while the least complications are renal failure, coma and ketoacidosis.

Similar findings were reported regarding retinopathy in UAE (54.2\%), ${ }^{17}$ Egypt $^{18}$ and Tunisia. ${ }^{19}$ Occurrence complications in DM is the question of importance of glycemic control; Epidemiologic studies showed a strong relationship between glycemia and diabetic complications, in both type I and type II diabetes. There is a continuous relationship between prevailing glycemia and risk of progression of complications, implying that any improvement in glycemic control is beneficial. ${ }^{20}$

The study has certain limitations; first the study is limited for three months that may not expose to the annual diabetic admission, the second it is a hospital-based study and may neglect disabled diabetic patients who receiving home care.

\section{Conclusions}

The prevalence of DM among hospitalized patients is high, and presenting with high proportion of symptoms and micro-vascular complications mainly retinopathy and food ulcer due to poor adherence to treatment.

\section{Declarations}

\section{Competing interest:}

The authors declare no competing interest

\section{References}

1. Giambrone T, Dunbar-Jacob J. The Relationship between Diabetes Duration and Glycemic Control among Patients with Multiple Chronic Diseases. In nursing Research 2016; 65 (2):15-16. 
2. Buysschaert M, Medina JL, Buysschaert B, Bergman M. Definitions (and Current Controversies) of Diabetes and Prediabetes. Curr. diabetes rev. 2015; 12(1):8-13.

3. American Diabetes Association. Standards of medical care for patients with diabetes mellitus. Puerto Rico Health Sciences Journal. 2013; 20(2).

4. Kaur N, Kishore L, Singh R. Attenuating diabetes: What really works?. Curr. diabetes rev. 2016 1;12(3):259-78.

5. WHO. Global report on diabetes. World Health Organization, Geneva, 2016, retrieved from http://www.who.int/diabetes/globalreport/en.

6. Aguiree, Florencia, Brown, Alex, Cho, Nam Ho, Dahlquist, Gisela, Dodd, Sheree, Dunning,Trisha, Hirst, Michael, Hwang, Christopher, Magliano, Dianna, Patterson, Chris, Scott, Courtney, Shaw, Jonathon, Soltesz, Gyula, Usher-Smith, Juliet and Whiting, David 2013, IDF Diabetes Atlas: sixth edition, 6th ed., International Diabetes Federation, Basel, Switzerland.

7. Meo SA, Sheikh SA, Sattar K, et al. Prevalence of Type 2 Diabetes Mellitus Among Men in the Middle East: A Retrospective Study. Am J Mens Health. 2019;13(3):1557988319848577. doi:10.1177/1557988319848577.

8. Molham Al-Habori., Mohamed Al-Mamari and Ali Al-Meeri, (2004). Type II Diabetes Mellitus and impaired glucose tolerance in Yemen: prevalence, associated metabolic changes and risk factors. Available on: http://www.researchgate.net/profile/Mohammed_Al-Mamary/publications/? pubType=article.

9. The Central Statistics Organization (CSO) /Syoun. Population projection 2019 Available at: http://sadaalwadi.net/?p=70899 accessed 4/10/2020).

10. Maori L, Ezekiel D, Bilal J, Alibe W, L.Haruna I. prevalence of diabetes mellitus in patients attending Zambuk General Hospital. Nigeria. 2014; 4: 10, view on https://www.researchgate.net/publication/271252108.

11. Aguiree, Florencia A et al. Diabetes Atlas: sixth edition, 6th ed., International Diabetes Federation, Basel, Switzerland. 2013,

12. Chowdhury, TA et al. Managing adults with diabetes in hospital during an acute illness.BMJ2017;357:j2551. doi:https://doi.org/10.1136/bmj.j2551

13. Seiglie $\mathrm{J}$ et al. Diabetes as a Risk Factor for Poor Early Outcomes in Patients Hospitalized With COVID-19. Diabetes Care 2020 Aug; dc201506. https://doi.org/10.2337/dc20-1506

14. Gizaw M, Harries AD, Ade S, et al. Diabetes mellitus in Addis Ababa, Ethiopia: admissions, complications and outcomes in a large referral hospital. Public Health Action. 2015;5(1):74-78. doi:10.5588/pha.14.0107

15. Clark NG, Fox KM, Grandy S. Symptoms of Diabetes and Their Association With the Risk and Presence of Diabetes. Diabetes Care 2007 Nov; 30(11): 2868-2873. https://doi.org/10.2337/dc070816 Available at: http://www.diabetes.org/diabetes/type-1/symptoms Accessed $12 / 10 / 2020$ 
16. Forbes JM, Cooper ME. Mechanisms of diabetic complications. Physiol Rev. 2013 Jan;93(1):137-88. doi: 10.1152/physrev.00045.2011. PMID: 23303908.

17. . Abdul Razzak H, Harbi A, shelpei W, Qawas A. Epidemiology of diabetes mellitus in United Arab Emirates. UAE. 2017;7 (13): 6-7, view on: https://www.researchgate.net/publication/319988118.

18. Hamed SA, Amine NF, Galal GM, Helal SR, Tag El-Din LM, Shawky OA, Abdel Rahman MS: Vascular risks and complications in diabetes mellitus: the role of helicobacter pylori infection. J Stroke Cerebrovask Dis 2008, 17(2):86-94.

19. Harzallah F, Ncibi N, Alberti H, Ben Brahim A, Smadhi H, Kanoun F, Slimane H: Clinical and metabolic characteristics of newly diagnosed diabetic patients: experience of a university hospital in Tunis. Diabetes Metab 2006 Dec, 32(6):632-635.

20. Skyler JS. Diabetic complications. The importance of glucose control. Endocrinol Metab Clin North Am. 1996 Jun;25(2):243-54. doi: 10.1016/s0889-8529(05)70323-6. PMID: 8799699.

\section{Figures}

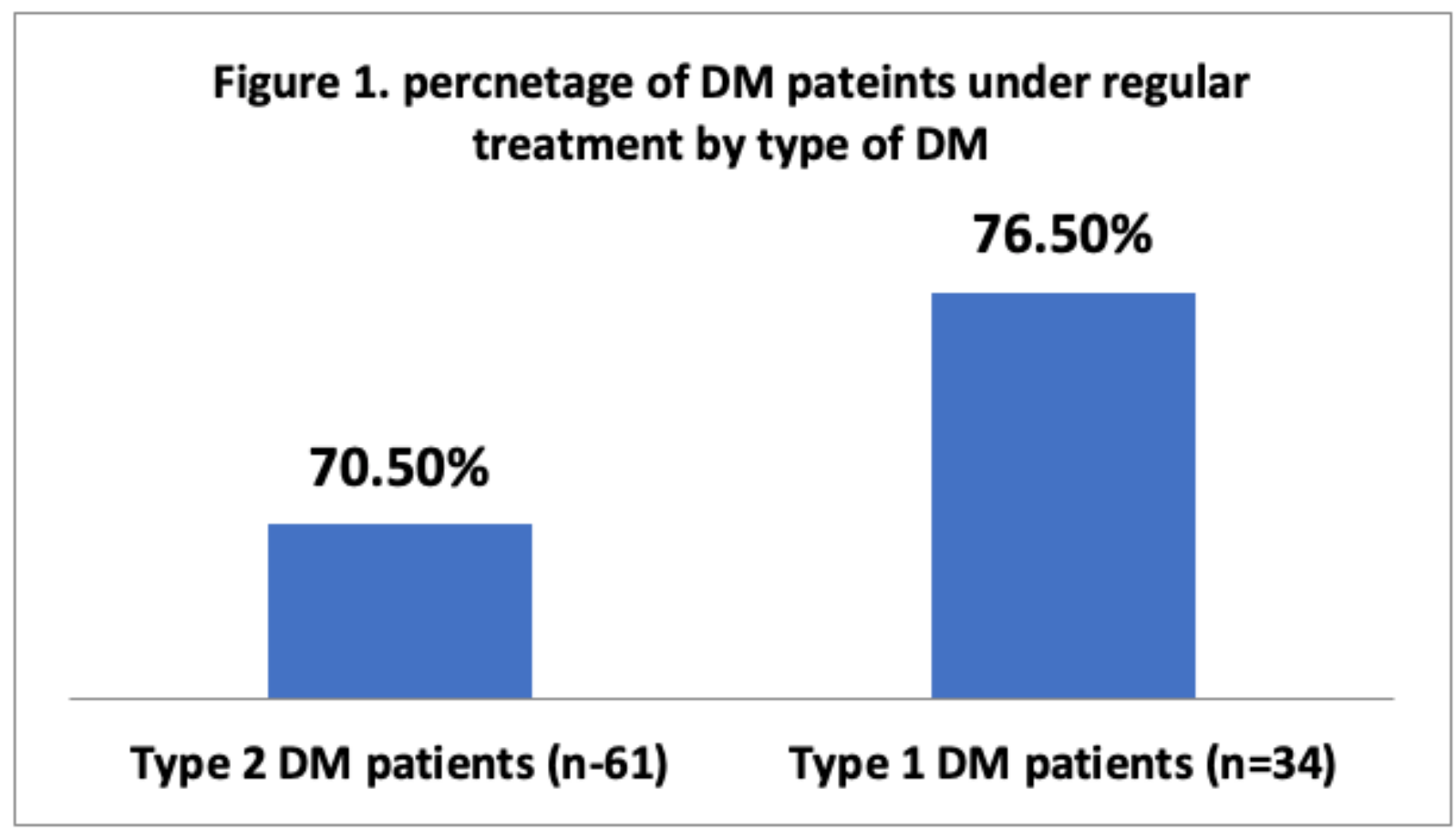

Figure 1

percentage of DM patents under regular treatment by type of DM 